\title{
Chemical Composition and Functional Properties of Dietary Fibre Concentrates from Winemaking By-Products: Skins, Stems and Lees
}

\author{
María Ángeles Rivas ${ }^{1,2}$, Rocío Casquete ${ }^{1,2, *(D)}$, María de Guía Córdoba 1,2 (D), Santiago Ruíz-Moyano ${ }^{1,2}$ (D), \\ María José Benito ${ }^{1,2} \mathbb{D}$, Francisco Pérez-Nevado ${ }^{1,2} \mathbb{D}$ and Alberto Martín ${ }^{1,2}$ (D) \\ 1 Nutrición y Bromatología, Escuela de Ingenierías Agrarias, Universidad de Extremadura, \\ Avd. Adolfo Suárez s/n, 06007 Badajoz, Spain; mrivasm@unex.es (M.Á.R.); mdeguia@unex.es (M.d.G.C.); \\ srmsh@unex.es (S.R.-M.); mjbenito@unex.es (M.J.B.); fpen@unex.es (F.P.-N.); amartin@unex.es (A.M.) \\ 2 Instituto Universitario de Investigación en Recursos Agrarios (INURA), Avd. de la Investigación, \\ Universidad de Extremadura, 06006 Badajoz, Spain \\ * Correspondence: rociocp@unex.es; Tel.: +34-924289300 (ext. 86228)
}

\section{check for}

updates

Citation: Rivas, M.Á.; Casquete, R.; Córdoba, M.d.G.; Ruíz-Moyano, S.; Benito, M.J.; Pérez-Nevado, F.; Martín, A. Chemical Composition and Functional Properties of Dietary Fibre Concentrates from Winemaking By-Products: Skins, Stems and Lees. Foods 2021, 10, 1510. https://doi.org/ $10.3390 /$ foods 10071510

Academic Editor: Theodoros Varzakas

Received: 28 May 2021

Accepted: 26 June 2021

Published: 30 June 2021

Publisher's Note: MDPI stays neutral with regard to jurisdictional claims in published maps and institutional affiliations.

Copyright: (c) 2021 by the authors. Licensee MDPI, Basel, Switzerland. This article is an open access article distributed under the terms and conditions of the Creative Commons Attribution (CC BY) license (https:// creativecommons.org/licenses/by/ $4.0 /)$

\begin{abstract}
The objective of this study was to evaluate, from a technological and nutritional point of view, the chemical composition and functional properties of the industrial winemaking by-products, namely skins, stems and lees. The chemical and physical characteristics, as well as the functional properties (fat and water retention and swelling capacity, antioxidant capacity, and their prebiotic effect), of the dietary fibre of these by-products were studied. The results showed that the skins, stems, and lees are rich in fibre, with the stem fibre containing the highest amounts of non-extractable polyphenols attached to polysaccharides with high antioxidant activity and prebiotic effect. Lee fibre had the highest water retention capacity and oil retention capacity. The results reveal that winemaking by-products could be used as a source of dietary fibre with functional characteristics for food applications.
\end{abstract}

Keywords: soluble and insoluble dietary fibre; non-extractable phenolic compounds; antioxidant capacity; neutral sugar; in vitro fermentation

\section{Introduction}

Waste from the agri-food industries is a current matter of global concern, with the generation of around 37 million tons of agricultural residues in the world during 2017 [1]. The generation of agricultural waste is particularly of concern in viticulture; it is estimated that $25 \mathrm{~kg}$ of waste is produced for every $100 \mathrm{~kg}$ of grapes [2]. This involves an economic and ecological problem in the management of the winemaking industries [3,4]. The recovery process plays an important role in the circular economy approach. It improves biomass value where the biorefinery acts as a platform that includes several conversion technologies $[5,6]$.

Industrial winemaking activities produce solid residues such as grape pomace (60\% of total wine by-products), which is mainly made up of grape skins (50\%), residual pulp and stalks (25\%) and seeds (25\%) [7]. In addition, another by-product to highlight is the wine lees that are produced during fermentation [8] and account for $25 \%$ of the waste produced [9-11]. These by-products are rich in dietary fibre (DF), being an important source of soluble polysaccharides [12-15] as well as antioxidant compounds [16-20]. Therefore, by-products of winemaking can be used to produce ingredients with suitable functional properties for the development of new food products. These by-products were used for novel biscuit formulation as an alternative to DF and phenolic compounds [21] and showed reduced oxidation of seafood and meats [22,23]. In addition, insoluble dietary fibre from grape pomace decreased tannins in red wine by up to $38 \%$, showing its efficacy as a clarifying agent in wines [24]. 
The functional properties of dietary fibre-including the water retention capacity (WRC), the swelling capacity (Sw), the fat retention capacity (FAC), antioxidant activity and prebiotic activity-are associated with the physicochemical characteristics of cell wall polysaccharides, varying according to their composition [25]. WRC, mainly related to insoluble dietary fibre (IDF), prevents and treats different intestinal disorders by increasing faecal bulk and reducing the gastrointestinal transit time. In food-technological terms, dietary fibre with high WRC can be used as a functional ingredient to avoid syneresis and to modify the viscosity and texture of some formulated foods, whereas dietary fibre with high FAC allows stabilisation of fat in emulsion-based products [26]. Sw in the stomach and an increase in viscosity of the digesta is associated with soluble dietary fibre (SDF), which slows down the absorption of nutrients from the intestinal mucosa and lowers the postprandial blood glucose and insulin responses [27].

The prebiotic effect of dietary fibre is probably the most important functional property. Dietary fibre reaches the colon, where it is fermented by the intestinal microbiota, generating short-chain fatty acids (SCFA), such as butyric, propionic, and acetic acids [28]. These compounds are associated with a wide range of physiological properties, including the improvement of digestive tract disorders [29-31] and anticancer activity [32,33].

In this context, the objective of this study was to analyse the chemical composition and the functional properties of skins, stems, and lees as by-products of industrial winemaking and thus offer new opportunities for waste use in the wine industry.

\section{Materials and Methods}

\subsection{Plant Material}

Winemaking by-products used in this work were provided by wineries from the Region of Extremadura, Spain. Winemaking by-products studied included red grape skins, stems, and wine lees from grapes of the Tempranillo variety. Grape skin and stem samples were taken after pressing the grapes. In the case of lees, samples were taken at the end of the fermentation. The samples were freeze-dried (LyoBeta, Telstar, Barcelona, Spain). The parameters of the freeze-drying process were freezed for $4 \mathrm{~h}$ at $-40{ }^{\circ} \mathrm{C}$ and primary drying $\left(8.5 \mathrm{~h}\right.$ at $-20^{\circ} \mathrm{C}$ and $6.5 \mathrm{~h}$ at $20^{\circ} \mathrm{C}$ ) at $400 \mu \mathrm{bar}$. The samples were then ground with a grinder and sieved with a fine mesh $(\max 1 \mathrm{~mm})$. Finally, the samples were vacuum-packed using a vacuum packing machine (Model SAMMIC SV-420, Gipuzkoa, Spain) and stored at room temperature until use. All determinations (Figure 1) were done in triplicate.

\subsection{Chemical Composition}

\subsubsection{Moisture and Ash}

The moisture and ash determinations were based on methods from AOAC International [34]. Moisture and ash content was determined by drying the samples at 105 and $500{ }^{\circ} \mathrm{C}$, respectively, until a constant weight was achieved.

\subsubsection{Crude Protein and Total Fat}

Crude protein was determined following the Kjeldahl method [35]. Fat content was determined gravimetrically by extraction with diethyl ether using a Soxhlet apparatus [36].

\subsubsection{Determination of Soluble Sugars}

Total soluble sugars (TSS) were extracted with distilled water and determined using the sulfuric acid-ultraviolet (UV) method proposed by Albalasmeh et al. [37]. Reducing sugars (RS) were determined by the dinitrosalicylic acid (DNS) method [38]. Calibration was performed with standard solutions of glucose. The results were expressed as $\mathrm{g} / 100 \mathrm{~g}$ dry sample. 


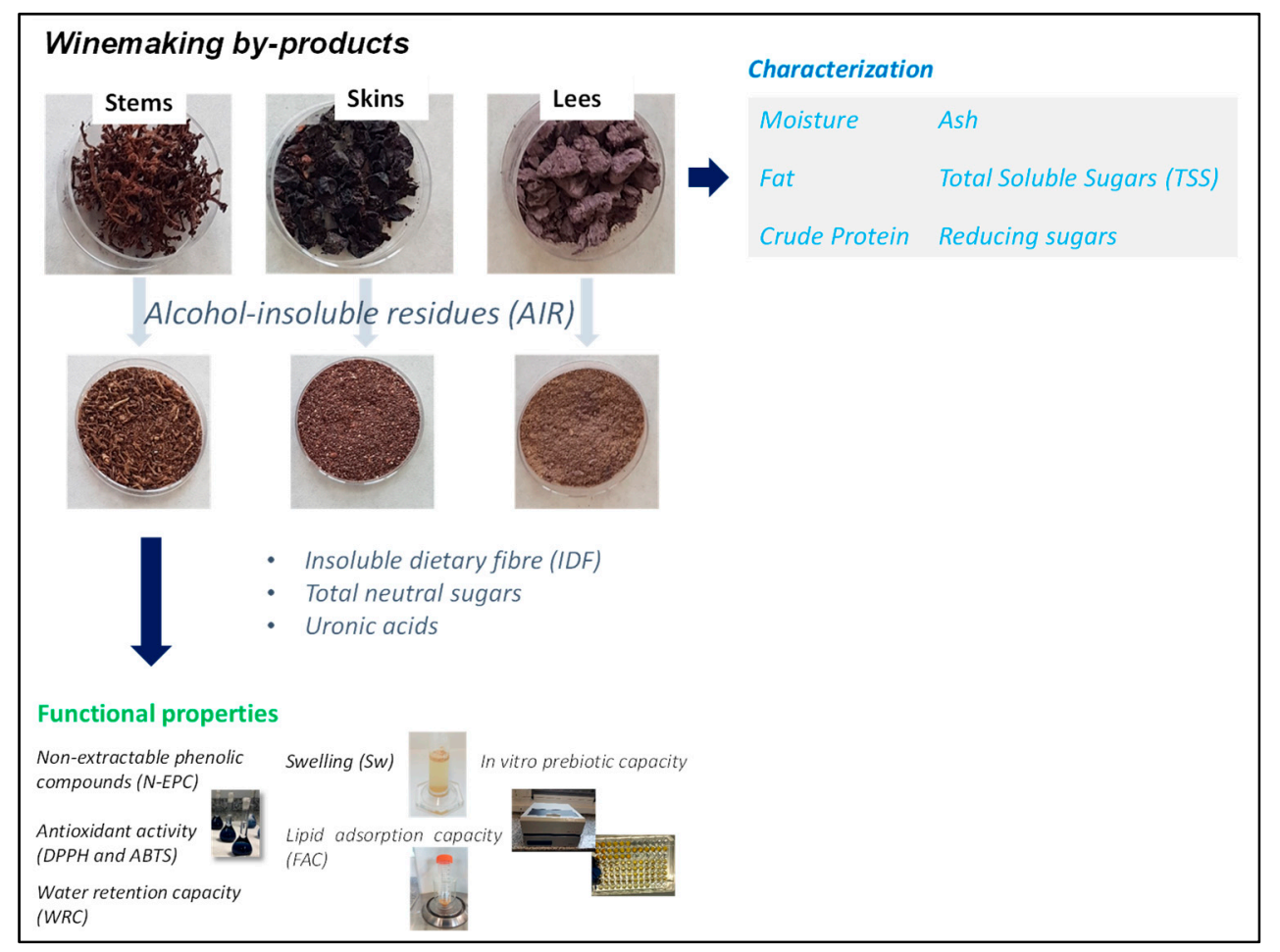

Figure 1. Graphic diagram of the study design.

For the characterisation of soluble sugars, the carbohydrates in $1 \mathrm{~mL}$ of solution were converted into alditol acetates and quantified by gas chromatography (Shimadzu 2010 Plus) following the method described by Bastos et al. [39]. A capillary column, DB-225 $(30 \mathrm{~m} \times 0.25 \mathrm{~mm}$ i.d.; $0.15 \mu \mathrm{m}$; Agilent, Santa Clara, CA, USA) and auto-injector (Shimadzu AOC-20i) were used. The temperatures of the FID detector and injector were 240 and $230{ }^{\circ} \mathrm{C}$, respectively. The oven temperature was initially held at $140{ }^{\circ} \mathrm{C}$ for $2.5 \mathrm{~min}$, then increased to $200{ }^{\circ} \mathrm{C}$ at a rate of $20^{\circ} \mathrm{C} / \mathrm{min}$ and held for $4.5 \mathrm{~min}$, after which it increased at a rate of $30{ }^{\circ} \mathrm{C} / \mathrm{min}$ to a final temperature of $220^{\circ} \mathrm{C}$, at which it was held for $18 \mathrm{~min}$. The injection volume was $1 \mu \mathrm{L}$ with a split ratio 1:10. Helium was used as a carrier gas at a flow rate of $1.49 \mathrm{~mL} / \mathrm{min}$. Components were identified by comparing their retention times with those of derivatised standards and quantified using 2-deoxyglucose as an internal standard. The results were expressed as $\mathrm{mg} / \mathrm{g}$ dry samples.

\subsubsection{Determination of Total, Soluble, and Insoluble Dietary Fibre}

The total dietary fibre (TDF) of winemaking by-products was measured following the standard enzymatic-gravimetric method [40]. First, $1 \mathrm{~g}$ of dry sample was mixed into $50 \mathrm{~mL}$ of distilled water. Then, samples were digested with $200 \mu \mathrm{L}$ of $\alpha$-amylase (Sigma-Aldrich, St. Louis, MO, USA) at $80^{\circ} \mathrm{C}$ for $1 \mathrm{~h}$ with constant agitation. After digestion, $100 \mu \mathrm{L}$ of amyloglucosidase solution $(50 \mathrm{mg} / \mathrm{mL}$ ) (Sigma-Aldrich) was added and the mixture was kept at $60^{\circ} \mathrm{C}$ for $3 \mathrm{~h}$. Next, the $\mathrm{pH}$ was adjusted to 7.0 with $\mathrm{NaOH} 10 \%(w / v)$, followed by incubation with $200 \mu \mathrm{L}$ of protease (Sigma-Aldrich) at $80^{\circ} \mathrm{C}$ for $1 \mathrm{~h}$. Finally, digested samples were vacuum filtered with cellulose-free filters (Whatman glass microfiber filters, 934-AHTM). The solid fraction contained in the filter represented insoluble dietary fibre (IDF). To precipitate the soluble dietary fibre (SDF), 4 volumes of $96 \%$ ethanol were added to the filtrate at $60^{\circ} \mathrm{C}$. Both fractions of fibre were dried overnight at $45^{\circ} \mathrm{C}$ in an oven and were then weighed. The TDF was calculated as the sum of IDF and SDF. The results were expressed as g/100 g dry sample. All experiments were conducted in triplicate. 


\subsection{Characterisation of Insoluble Fibre: Cellulose, Hemicellulose, and Lignin}

The determination of cellulose, hemicellulose and lignin was carried out by calculating the fractions of neutral detergent fibre (NDF) and acid detergent fibre (ADF) [41] in a fibre extractor (Dosi-Fiber, J.P. Selecta, Abrera, Spain). The ADF determination consisted of boiling the sample with cetyltrimethylammonium bromide in an acid medium with subsequent filtration and washing of the residue. This method resulted in a good estimate for cellulose and lignin. For NDF determination, the sample was treated with a hot solution of sodium lauryl sulphate with a subsequent gravimetric determination of the residue. This method gives a good estimate of insoluble fibre (cellulose, hemicellulose, and lignin). The difference between NDF and ADF was the hemicellulose content. The cellulose, hemicellulose, and lignin contents were expressed as $\mathrm{mg} / 100 \mathrm{~g}$ of fibre.

\subsection{Characterisation of Soluble Fibre: Neutral Sugar and Pectins}

Extraction of dietary fibre from the winemaking by-products was carried out using a modification of the double residue method in alcohol to determine the alcohol-insoluble residue (AIR) described by Femenia et al. [42]. Briefly, 3 replicates ( 5 g each) of the dry sample were homogenised with $85 \%(v / v)$ ethanol. The mixture was boiled on a shaker for $10 \mathrm{~min}$, and then the solid residue was collected using a Büchner funnel with cellulose-free filters (Whatman, 934-AHTM glass microfiber filters). This process was repeated twice, the last time with absolute ethanol. Finally, the insoluble solid residue was washed with acetone, and the excess solvent was removed after $24 \mathrm{~h}$ at room temperature.

Total neutral sugars (TNS) were released through a process of hydrolysis of the fibre using $12 \mathrm{M}$ sulfuric acid ( $3 \mathrm{~h}$ at room temperature and $100^{\circ} \mathrm{C}$ for $1 \mathrm{~h}$ ) and were determined, as D-glucose equivalent, with the anthrone method proposed by Van Handel [43].

For the characterisation of neutral sugars (rhamnose, fucose, arabinose, xylose, mannose, galactose, and glucose), neutral sugars were converted into their alditol acetates and quantified by gas chromatography as described in Section 2.2.2. The content of each individual neutral sugar was expressed as $\mathrm{mg} / \mathrm{g}$.

The uronic acid content was determined spectrophotometrically by the m-hydroxydiphenyl method [44] with galacturonic acid as standard and 3,5-dimethylphenol as reagent. The results were expressed as $\mathrm{mg}$ galacturonic acid/g AIR.

\subsection{Functional Properties of the Fibre}

\subsubsection{Swelling, Water Retention Capacity and Fat Retention Capacity}

Sw, WRC and FAC determinations were carried out following the method described by Garau et al. [45]. For Sw, $0.1 \mathrm{~g}$ of AIR was mixed with $10 \mathrm{~mL}$ of distilled water on a calibrated cylinder. After $24 \mathrm{~h}$ incubation at room temperature $\left(20-25^{\circ} \mathrm{C}\right)$, the increase in volume was measured, and the results were expressed as $\mathrm{mL}$ water/g AIR. For WRC, $0.2 \mathrm{~g}$ of AIR was hydrated in $10 \mathrm{~mL}$ of distilled water and left for $24 \mathrm{~h}$ at room temperature (20$25^{\circ} \mathrm{C}$ ). The next day, the sample was centrifuged at $2000 \times g$ for $25 \mathrm{~min}$. After centrifugation, the supernatant was decanted, and the resulting solid residue was weighed. WRC was expressed as $\mathrm{g}$ water/g AIR. For FAC, the process was the same as for WRC determination, using $5 \mathrm{~mL}$ of sunflower oil in place of the $10 \mathrm{~mL}$ of water. The results were expressed as $\mathrm{g}$ oil/g AIR.

\subsubsection{Non-Extractable Polyphenols and Antioxidant Activity}

The determination of the antioxidant capacity of non-extractable polyphenols bound to AIR was achieved according to the method described by Arranz et al. [46] with some modifications. A total of $0.5 \mathrm{~g}$ of AIR was mixed with $20 \mathrm{~mL}$ of a methanol/water solution (50: 50) acidified with hydrochloric acid to $\mathrm{pH} 2$. The mixture was incubated with stirring for $1 \mathrm{~h}$ and subsequently centrifuged for $20 \mathrm{~min}$ at $2500 \times \mathrm{g}$. This process was repeated with an acetone/water solution (70: 30$)$. The excess solution was removed by heating at $37^{\circ} \mathrm{C}$ in a rotary evaporator under vacuum (Hei-VAP Precision, Heidolph, Germany). The resultant residue was resuspended in $30 \mathrm{~mL}$ of distilled water. The total non-extractable 
polyphenols bound to AIR were determined using the Folin-Ciocalteure agent [47] in a UV-1800 spectrophotometer (Shimadzu Scientific Instruments, Columbia, MD, USA). Gallic acid was used as the standard. The results were expressed as mg gallic acid equivalent (GAE)/100 g AIR.

The antioxidant capacity of the samples was evaluated by 2 antioxidant assay methods: the 2,2-diphenyl-1-picrilhydrazyl (DPPH) depletion method according to the procedure of Teixeira et al. [48], and the capacity to remove the 2,2'-azinobis (3-ethylbenzothiazoline-6sulfonic acid) (ABTS) radical according to the method of Re et al. [49]. Trolox was used as the standard, and the results were expressed as mg Trolox equivalent/100 g AIR.

\subsubsection{In Vitro Prebiotic Capacity}

The prebiotic capacity of the soluble dietary fibre extracts on lactic acid bacteria (LAB) associated with fermented food products was determined using the method described previously by Ruiz-Moyano et al. [50]. For this study Lactococcus lactis (CECT 188), Lactobacillus curvatus (CECT 904), Lactobacillus sakei (CECT 5765 and CECT 980), Lactobacillus brevis (CECT 815), Lactobacillus plantarum (G1LB5; [46]), Lactobacillus casei (HL 245 and HL 233; [51]) and Enterococcus faecium (SE 906 and SE 920; [52]) were used. Prior to the assay, LAB were grown in de Man-Rogosa-Sharpe broth (MRS; Condalab, Madrid, Spain) at $37^{\circ} \mathrm{C}$ for $24 \mathrm{~h}$. The strains were tested for growth in the presence of solubilised AIR (autoclaved at $121{ }^{\circ} \mathrm{C}$ for $16 \mathrm{~min}$ followed by an ultrasound treatment for $1 \mathrm{~h}$ ). The absence of free sugars in each solubilised AIR was previously checked. For each bacterial strain, $5 \mu \mathrm{L}$ of suspension was inoculated in $200 \mu \mathrm{L}$ of semi-solid MRS medium containing $0.125 \mathrm{~g} / \mathrm{L}$ agar without glucose and supplemented with $2 \mathrm{~g} / \mathrm{L}$ of each sterile filtered dietary fibre extract as the sole carbohydrate source. The positive control for growth consisted of semi-solid MRS supplemented with $2 \mathrm{~g} / \mathrm{L}$ glucose, whereas the negative control was a carbohydrate-free semi-solid MRS. Turbidity was measured in a fluorescence microplate reader (FLUOstar OPTIMA F, BMG Labtech, Ortenberg, Germany), growth was carried out for $48 \mathrm{~h}$ at a temperature of $37^{\circ} \mathrm{C}$, with readings at a wavelength of $570 \mathrm{~nm}$ every $1 \mathrm{~h}$. For each strain, the ability to grow was evaluated by comparing the percentage growth in each extract with the positive control.

\subsection{Statistical Analysis}

Statistical analysis of the data was carried out using SPSS for Windows, version 21.0 (IBM Corp., Armonk, NY, USA). Descriptive statistics of the data were determined, and the differences within and between groups were studied by one-way analysis of variance (ANOVA) and separated by Tukey's honest significant difference test $(p \leq 0.05)$. Principal component analysis (PCA) was performed on the correlation matrix of the variables.

\section{Results and Discussion}

\subsection{General Chemical Composition}

The results of the chemical composition of winemaking by-products (skins, stems and lees) are shown in Table 1 . The stem samples showed higher moisture values $(p \leq 0.05)$ than the skin and the lee samples, reaching $16.26 \%$. The lowest moisture value corresponded to the skin samples, with a value of $7.66 \%$. However, the ash content of the lee samples was $13.18 \%$, which was significantly higher than the amount found in other samples, ranging from $6.08 \%$ for stems up to $8.12 \%$ for the skin. The samples with the highest crude protein content were lees $(22.32 \%)$, followed by skin and stem samples, with values of $12.24 \%$ and $7.94 \%$, respectively. The fat content ranged from 1.95 to $4.85 \%$ (Table 1), not showing significant differences between samples (skins, stems and lees). The fact that the lees were the by-product with the highest percentage of proteins was explained by the nature of the residue; lees were mainly made up of the remains of the yeast autolysis during the process of fermentation. In the same way, Rubio et al. [53] also found higher protein content in lees, followed by skin and stems. The values obtained from skin samples agreed with those published by Deng et al. [54]. However, the stem and lees values differed from those found 
by González-Centeno et al. [55] and Bordiga [56]. The composition depended on numerous parameters related to the types of grapes and in the case of the lees the type of yeast used, and to the vinification method, resulting in a wide compositional heterogeneity, as shown by data reported in the literature [57].

Table 1. Chemical composition of skins, stems, and lees ( $\mathrm{g} / 100 \mathrm{~g}$ dry weight).

\begin{tabular}{lccc}
\hline \multicolumn{1}{c}{ Parameters } & Skins & Stems & Lees \\
\hline & Mean SD $^{\mathbf{1}}$ & Mean SD & Mean SD \\
\hline Moisture & $7.66 \pm 0.15^{\mathrm{a}}$ & $16.26 \pm 0.16^{\mathrm{c}}$ & $9.09 \pm 0.27^{\mathrm{b}}$ \\
Ash & $8.12 \pm 1.40^{\mathrm{a}}$ & $6.08 \pm 1.18^{\mathrm{a}}$ & $13.18 \pm 0.92^{\mathrm{b}}$ \\
Protein & $12.24 \pm 0.88^{\mathrm{b}}$ & $7.94 \pm 0.35^{\mathrm{a}}$ & $20.32 \pm 0.75^{\mathrm{c}}$ \\
Fat & $4.24 \pm 0.93^{\mathrm{a}}$ & $1.95 \pm 0.39^{\mathrm{b}}$ & $4.85 \pm 1.15^{\mathrm{a}}$ \\
TSS & $3.65 \pm 0.35^{\mathrm{a}}$ & $22.01 \pm 1.56^{\mathrm{b}}$ & $1.63 \pm 0.09^{\mathrm{a}}$ \\
Reducing sugars & $1.78 \pm 0.08^{\mathrm{a}}$ & $19.60 \pm 2.37^{\mathrm{b}}$ & $0.49 \pm 0.05^{\mathrm{a}}$ \\
Glucose & $0.90 \pm 0.73^{\mathrm{a}}$ & $10.62 \pm 11.22^{\mathrm{b}}$ & $<0.5^{* a}$ \\
Fructose & $0.79 \pm 0.54^{\mathrm{a}}$ & $11.71 \pm 12.01^{\mathrm{b}}$ & $<0.5^{* a}$ \\
TDF & $82.30 \pm 2.71^{\mathrm{b}}$ & $71.39 \pm 1.01^{\mathrm{a}}$ & $82.32 \pm 1.69^{\mathrm{b}}$ \\
IDF & $78.18 \pm 2.91^{\mathrm{b}}$ & $67.68 \pm 0.95^{\mathrm{a}}$ & $78.43 \pm 1.32^{\mathrm{b}}$ \\
SDF & $4.13 \pm 0.20^{\mathrm{a}}$ & $3.71 \pm 0.06$ & $3.90 \pm 0.37^{\circ}$ \\
\hline
\end{tabular}

TSS, total soluble sugars; TDF, total dietary fibre; IDF, insoluble dietary fibre; SDF, soluble dietary fibre. ${ }^{1} \mathrm{SD}$, standard deviation. * The limit of detection was $0.5 \mathrm{mg} / \mathrm{g}$. ${ }^{\mathrm{a}, \mathrm{b}, \mathrm{c}}$ Values with different superscripts are significantly different $(p \leq 0.05)$ between samples.

\subsubsection{Total Soluble Sugars}

Table 1 also shows the TSS content of the winemaking by-products. The values of total and reducing sugars (consisting of similar amounts of glucose and fructose) were highest in stem samples, with 22.01 and $19.60 \mathrm{~g} / 100 \mathrm{~g}$, respectively, because this by-product does not undergo fermentation [53]. On the contrary, the lees extracted when the malolactic fermentation had finished contained the lowest TSS content because they were transformed into alcohol.

\subsubsection{Total, Insoluble and Soluble Dietary Fibre}

The samples of skin, stem and lees studied were rich in TDF (71.39-82.32 g/100 g) and in IDF (Table 1). IDF has been described as the predominant dietary fibre fraction for winemaking by-products [58]. The IDF content from samples ranged from 67.68 to $78.43 \mathrm{~g} / 100 \mathrm{~g}$, showing higher values for lees and skin (Table 1). The content of SDF was similar for each of the by-products studied, with values between 3.71 and $4.13 \mathrm{~g} / 100 \mathrm{~g}$. The values obtained from TDF agreed with those published by other authors for skin and stem samples $[59,60]$. However, the composition of dietary fibre in winemaking lees continued to create controversy: some authors affirm that lees do not contain a significant fraction of dietary fibre [61], while other authors state that the content is around $22-50 \%$ [53]. The high dietary fibre content found in this work for lees has not been reported in previous publications. The high variability of these data was probably due to the different recovery methods, winemaking procedures applied, and varieties of grape.

\subsection{Fibre Constituents: Cellulose, Hemicellulose, Lignin, Neutral Sugars, and Pectins}

In skin, stems and lee samples, insoluble dietary fibre is mainly lignin (47.31, 29.83, and $44.41 \mathrm{~g} / 100 \mathrm{~g}$, respectively), followed by hemicellulose and cellulose (Table 2). The values obtained for lignin, cellulose and hemicellulose in the skin, stems and lee samples were similar to those reported in the literature [53,62-64]. 
Table 2. Fibre constituents of skins, stems and lees.

\begin{tabular}{lccc}
\hline \multirow{2}{*}{ Parameters } & Skins & Stems & Lees \\
\cline { 2 - 4 } & Mean SD & Mean SD & Mean SD \\
\hline IDF (g/100 g) & & & \\
$\quad$ Hemicellulose & $22.57 \pm 2.16$ & $17.18 \pm 0.22$ & $28.79 \pm 9.25$ \\
Cellulose & $7.24 \pm 0.04^{\mathrm{a}}$ & $14.55 \pm 3.59^{\mathrm{a}}$ & $30.03 \pm 0.54^{\mathrm{b}}$ \\
Lignin & $47.31 \pm 3.61^{\mathrm{b}}$ & $29.83 \pm 3.27^{\mathrm{a}}$ & $44.41 \pm 5.91^{\mathrm{b}}$ \\
Total neutral sugars of AIR (mg/g) & $114.71 \pm 19.04^{\mathrm{b}}$ & $84.82 \pm 16.76^{\mathrm{a}}$ & $156.04 \pm 8.82^{\mathrm{c}}$ \\
$\quad$ Rhamnose & $<0.5^{* \mathrm{a}}$ & $<0.5^{* \mathrm{a}}$ & $50.33 \pm 0.95^{\mathrm{b}}$ \\
Fucose & $32.37 \pm 2.51^{\mathrm{b}}$ & $12.40 \pm 11.31^{\mathrm{ab}}$ & $2.32 \pm 0.47^{\mathrm{a}}$ \\
Xylose & $11.76 \pm 1.15^{\mathrm{b}}$ & $<0.5^{* \mathrm{a}}$ & $<0.5^{* \mathrm{a}}$ \\
Mannose & $19.61 \pm 0.77^{\mathrm{a}}$ & $17.94 \pm 4.42^{\mathrm{a}}$ & $35.63 \pm 1.32^{\mathrm{b}}$ \\
Glucose & $26.07 \pm 1.06^{\mathrm{a}}$ & $28.07 \pm 5.30^{\mathrm{a}}$ & $78.30 \pm 1.45^{\mathrm{b}}$ \\
Galactose & $7.56 \pm 1.97^{\mathrm{b}}$ & $<0.5^{* \mathrm{a}}$ & $<0.5^{* \mathrm{a}}$ \\
Arabinose & $17.90 \pm 0.66^{\mathrm{b}}$ & $4.08 \pm 0.57^{\mathrm{a}}$ & $5.30 \pm 1.76^{\mathrm{a}}$ \\
Uronic acids of AIR (mg/g) & & & \\
Uronic acids (pectin) & $31.37 \pm 1.47^{\mathrm{b}}$ & $31.09 \pm 3.17^{\mathrm{b}}$ & $12.37 \pm 0.53^{\mathrm{a}}$ \\
\hline
\end{tabular}

IDF, insoluble dietary fibre; AIR, alcohol-insoluble residue. ${ }^{1} \mathrm{SD}$, standard deviation. ${ }^{*}$ The limit of detection was $0.5 \mathrm{mg} / \mathrm{g}$. ${ }^{\mathrm{a}, \mathrm{b}, \mathrm{c}}$ Values with different superscripts are significantly different $(p \leq 0.05)$ between samples.

The most abundant sugars in the AIR of the skin and the stems (Table 2) were uronic acids (which indicate the pectin content), followed by glucose and fucose in the case of the skin, and mannose in the stems, while arabinose, xylose, galactose and rhamnose were the minority sugars. In the case of lees, glucose was the major monosaccharide, followed by rhamnose and mannose, with concentrations around 78, 50 and $35 \mathrm{~g} / 100 \mathrm{~g}$, respectively. Uronic acids, fucose and arabinose values were lower in the lees than in skin and stems (Table 2). The profile found for the sugar composition of skin and stem agreed in general with the results obtained by other authors [55,65], although other authors have described pectin (measured as galacturonic acid equivalent) and glucose as the major skin and stem cell wall components [66]. High glucose levels could be related to high glucan and xyloglucan values [66-68].

With respect to xylose and fucose, higher amounts were found in skin samples than those described by other authors for these winemaking by-products $[67,69,70]$. The presence of xylose and fucose could indicate a higher amount of hemicellulosic polysaccharides in grape skins [71]. Ortega-Regules et al. [72] showed that the neutral sugar profile of the vinification by-products was highly variable, depending on the cultivar used. The degree of maturation of the grapes, their geographical origin and oenological techniques were also responsible for the differences found in the chemical composition of the by-products [66,73].

On the other hand, there were few studies on the profile of neutral sugars in winemaking lees, although some authors have reported that the main monosaccharides of lees were glucose, mannose and rhamnose $[74,75]$, which agreed with the data of our study.

\subsection{Functional Properties of the Fibre}

\subsubsection{Swelling, Water Retention Capacity and Oil Retention Capacity}

The functional properties of dietary fibres (Sw, WRC and FAC) were important in determining suitability for application as functional ingredients in foods. The results of these functional property analyses of winemaking by-products are shown in Table 3 . 
Table 3. Functional properties and non-extractable phenolic compounds (N-EPC) of dietary fibre from skins, stems and lees.

\begin{tabular}{lccc}
\hline \multicolumn{1}{c}{ Parameters } & Skins & Stems & Lees \\
\hline & Mean SD $^{\mathbf{1}}$ & Mean SD & Mean SD \\
\hline Sw (mL water/g) & $6.55 \pm 0.03^{\mathrm{a}}$ & $7.76 \pm 0.54^{\mathrm{ab}}$ & $8.43 \pm 0.47^{\mathrm{b}}$ \\
WRC (g water/g) & $4.57 \pm 0.21$ & $4.61 \pm 0.34$ & $9.11 \pm 2.39$ \\
FAC (g oil/g) & $3.76 \pm 0.27$ & $5.48 \pm 0.51$ & $5.48 \pm 0.88$ \\
N-EPC (mg GAE/100 g) & $92.83 \pm 15.76^{\mathrm{b}}$ & $138.63 \pm 28.68^{\mathrm{c}}$ & $44.64 \pm 4^{\mathrm{a}}$ \\
DPPH (mg Trolox/100 g) & $3823.68 \pm 63.65^{\mathrm{b}}$ & $6093.01 \pm 376.40^{\mathrm{c}}$ & $2049.23 \pm 33.73^{\mathrm{a}}$ \\
ABTS (mg Trolox/100 g) & $4205.82 \pm 307.11^{\mathrm{b}}$ & $5682.74 \pm 308.97^{\mathrm{c}}$ & $2395.50 \pm 671.69^{\mathrm{a}}$ \\
\hline
\end{tabular}

Sw, swelling water capacity; WRC, water retention capacity; FAC, oil retention capacity; GAE, gallic acid equivalents; DPPH and ABTS, antioxidant capacity. ${ }^{1}$ SD, standard deviation. ${ }^{a, b, c}$ Values with different superscripts are significantly different $(p \leq 0.05)$ between samples.

The Sw values, related to the porosity of the fibre [76], were significantly higher for the lee samples than for skin samples. However, the values of WRC and FAC did not show differences between the three by-products studied (Table 3). These values were similar to those published by other authors for winemaking by-products [55]. However, the stem samples showed lower values of WRC than those reported in previous studies, ranging from 5.5 to $10.7 \mathrm{~g}$ water/g AIR [55]. These differences may be due to the nature of the plant material used, in particular the IDF content. The structure and chemical composition of the fibre were known to play an important role in the kinetics of water absorption [77,78]. The high FAC values obtained in the stem and lee samples are beneficial because they are associated with oil retention during the digestion of food and reduce serum cholesterol levels [79].

In summary, the lee samples exhibited the best characteristics for use as a functional food ingredient, although these properties not only depend on the type of soluble fibre, but also on the particle size distribution and the characteristics of the surface [80]. In addition, the particle size may cause changes in the functional properties of dietary fibre, thus smaller particle sizes showed higher values of WRC and Sw [80].

\subsubsection{Non-Extractable Polyphenols and Antioxidant Activity}

The phenolic compound content in AIR (N-EPC) and the antioxidant capacity, determined by two methods (DPPH and ABTS), are also shown in Table 3. Among the three AIRs, stem AIR presented the highest N-EPC value of $138.63 \mathrm{mg}$ GAE/100 g, whereas lees AIR had the lowest N-EPC value of $44.64 \mathrm{mg}$ GAE / $100 \mathrm{~g}$. This difference may be due to the lignin content of each of the samples (Table 2). Bender et al. [62] observed that the concentration of phenolic compounds increased with reduced lignin content because of the breakdown of the lignin structure. Changes in the structure of the fibre affected the non-extractable phenolic compound content by loosening the hydrogen bonds and causing delignification [81].

Regarding DPPH and ABTS values, significant differences were found between the samples of by-products studied (Table 3). The stem samples showed the highest antioxidant activity both by the DPPH method (6093.01 mg Trolox/100 g) and ABTS (5682.74 mg Trolox/100 g), followed by skin and lee samples in agreement with the total phenolic content observed in samples (Table 3). In fact, there was a highly significant correlation $(\mathrm{r}=0.961 ; p<0.01)$ between the content of phenolic compounds of the fibre and its antioxidant activity by the DPPH method. The results reflect that the increase in antioxidant activity was promoted by the non-extractable total phenolic content. This mechanism has been corroborated by previous studies [82-84]. Ferri et al. [82] reported that seeds and raw skin extracts of several grape cultivars exhibited a high antioxidant capacity measured by the ABTS method, which was positively correlated with the total polyphenol content. 


\subsubsection{In Vitro Prebiotic Capacity}

Table 4 shows the capacity of the $10 \mathrm{LAB}$ strains tested for in vitro growth on three extracts of dietary fibre, observing differences in the growth of the strains according to the fibre used. Even though we expected higher bacterial growth on culture media with the skin fibre, due to the presence of fermentable fibre components such as pectins and hemicelluloses, we only observed low growth (Table 4). This growth was similar to growth on culture media with the lees fibre. The culture media enriched with the dietary fibre extracted from the stem samples presented the highest percentage of growth for all strains studied. The superior growth of bacteria with stem fibre could be related to the presence of the non-extractable polyphenols (Table 3). The data obtained could suggest that the studied strains use some phenols for their metabolism. This finding agrees with the study by Landete et al. [85]. The authors demonstrated that bacteria such as Lactobacillus spp. can degrade phenolic compounds to other molecules with high added value. Nonetheless, more studies would be needed in relation to the structures of the oligosaccharides present to know the potential of the grape stem as prebiotics. E. faecium SE $906 \mathrm{E}$ had the highest growth percentage (76.79\%), followed by L. sakei CECT 5765 (67.11\%) and E. faecium SE 920 $(62.46 \%)$ with moderate growth, showing differences from the rest of the strains $(p \leq 0.05)$.

Table 4. Percentage of growth of lactic acid bacteria (LAB) strains, with respect to the positive control, on soluble dietary fibre extracts of skins, stems and lees.

\begin{tabular}{lccc}
\hline \multicolumn{1}{c}{ Microorganisms } & Skins & Stems & Lees \\
\hline & Mean SD * & Mean SD & Mean SD \\
\hline Lactobacillus curvatus CECT 904 & $11.04 \pm 0.86^{\mathrm{a} 1,2}$ & $25.83 \pm 0.77^{\mathrm{b} 1}$ & $11.04 \pm 0.86^{\mathrm{a} 1,2}$ \\
Lactococcus lactis CECT 188 $_{\text {Lactobacillus sakei CECT 5765 }}$ & $9.28 \pm 0.76^{\mathrm{b} 1}$ & $26.74 \pm 0.06^{\mathrm{c} 1}$ & $6.00 \pm 0.34^{\mathrm{a} 1}$ \\
L. sakei CECT 980 & $28.74 \pm 2.59^{\mathrm{a} 4,5}$ & $67.11 \pm 0.85^{\mathrm{b} 3,4}$ & $27.11 \pm 0.05^{\mathrm{a} 4}$ \\
Lactobacillus brevis CECT 815 & $20.08 \pm 1.08^{\mathrm{b} 2,3,4}$ & $44.61 \pm 1.58^{\mathrm{c} 2}$ & $14.08 \pm 0.57^{\mathrm{a} 2,3}$ \\
Lactobacillus plantarum G1LB5 & $10.42 \pm 0.64^{\mathrm{a} 1}$ & $29.90 \pm 0.58^{\mathrm{c} 1}$ & $14.12 \pm 0.43^{\mathrm{b} 2,3}$ \\
Lactobacillus casei HL 245 & $10.30 \pm 0.89^{\mathrm{a} 1,2}$ & $33.50 \pm 8.62^{\mathrm{b} 1,2}$ & $8.17 \pm 0.54^{\mathrm{a} 1,2}$ \\
L. casei HL 233 & $39.65 \pm 3.51^{\mathrm{b} 1,2}$ & $12.19 \pm 4.08^{\mathrm{a} 1,2,3}$ \\
Enterococcus faecium SE 906 & $30.52 \pm 6.92^{\mathrm{a} 1,2,3}$ & $47.39 \pm 0.08^{\mathrm{b} 2}$ & $13.28 \pm 4.65^{\mathrm{a} 1,2,3}$ \\
E. faecium SE 920 & $22.49 \pm 0.68^{\mathrm{b} 3,4,5}$ & $76.79 \pm 0.48^{\mathrm{b} 4}$ & $23.02 \pm 3.79^{\mathrm{a} 4}$ \\
\hline
\end{tabular}

*SD, standard deviation. ${ }^{a, b, c}$ Values with different superscripts are significantly different $(p \leq 0.05)$ between samples. ${ }^{1,2,3,4,5}$ Values with different subscripts are significantly different $(p \leq 0.05)$ between strains in one sample. Negative growth $(<20 \%)$. Slight growth $(20-40 \%)$, Moderate growth $(40-70 \%)$. High growth $(>70 \%)$.

\subsection{Multivariate Analysis of the Parameters Related to Dietary Fibre Extracted from Skin, Stems and Lees}

PCA was carried out for the entire set of dietary fibre data to obtain an interpretable overview of the main information. Figure 2 shows the two-way loadings and score plots, where PC2 was plotted against PC1, explaining more than $90 \%$ of the total variance. Higher values for AIR, N-EPC, antioxidant activity (DPPH and ABTS) and bacterial growth were clearly correlated and explained the positive axis of PC1, which was related to the stem samples. Therefore, the principal component analysis confirmed the results shown previously, indicating that the increase in antioxidant activity was promoted by the N-EPC content and that the culture media enriched with the dietary fibre extracted from the stem samples showed the highest percentage of growth. On the contrary, TNS and functional properties (WRC and FAC) explained the negative axis of PC1 and were associated with lee samples. The second PC was mainly explained by neutral sugars (galactose, arabinose, and xylose) located in the extreme of the negative axis, relating to high values in skin samples. 


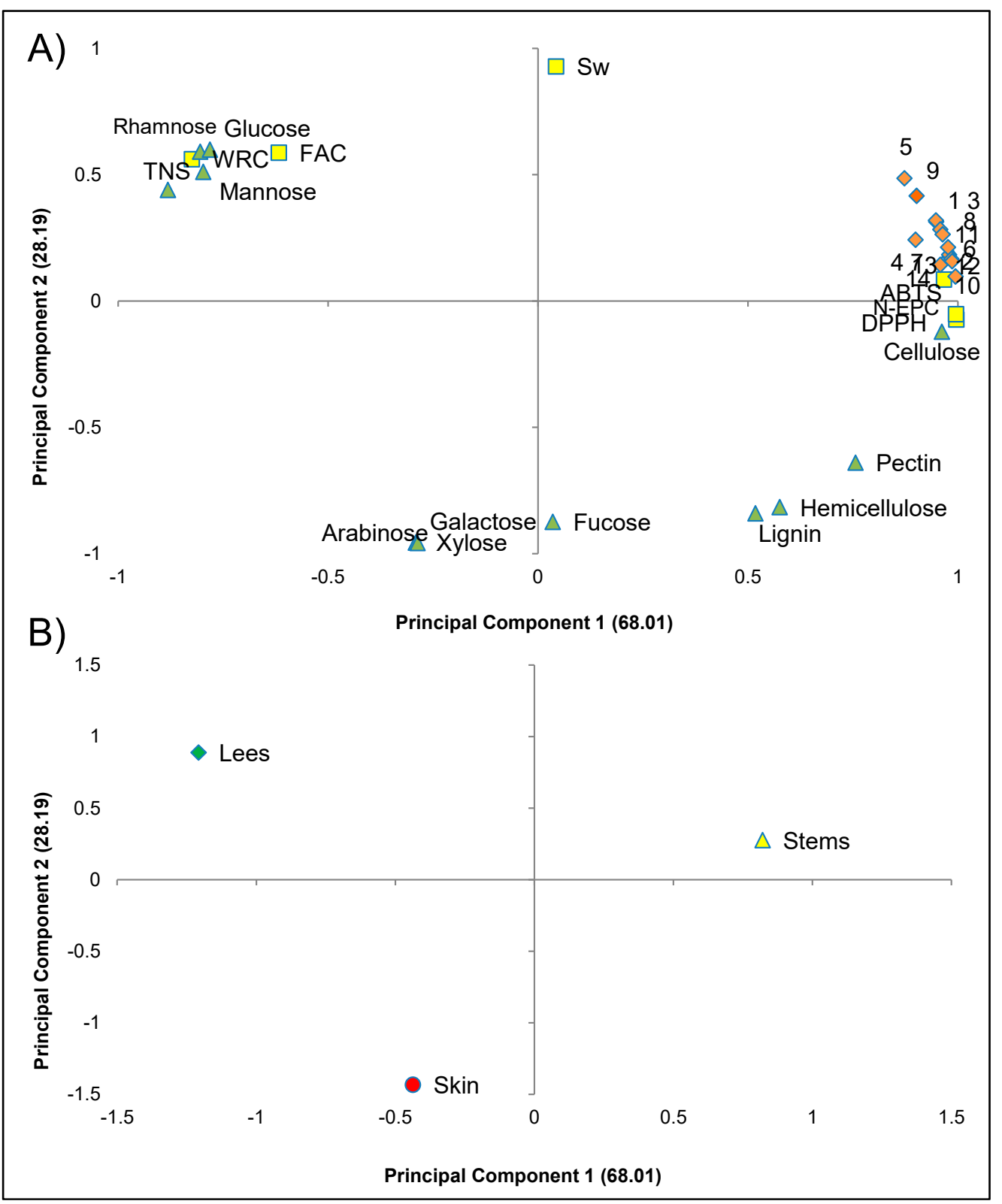

Figure 2. Principal component analysis of the analytical results of dietary fibre from skin, stems and lee samples. Loading plot (A). TNS, total neutral sugar; N-EPC, non-extractable phenolic compounds; DPPH and ABTS, antioxidant activity; Sw, swelling; WRC, water retention capacity; FAC, fat retention capacity; Bacterial growth: 1, Lactobacillus curvatus CECT 904; 2, Lactococcus lactis CECT 188; 3, Lactobacillus sakei CECT 5765; 4, Lactobacillus sakei CECT 980; 5, Lactobacillus brevis CECT 815; 6, Lactobacillus plantarum G1LB5; 7, Lactobacillus casei HL 245; 8, L. casei HL 233; 9, Enterococcus faecium SB 906; 10, E. faecium SB 920. Score plot (B). Skin, stem, and lees sample.

\section{Conclusions}

This study presents a complete physical and chemical characterisation of three winemaking by-products: skins, stems and lees. These by-products, rich in fibre, were demonstrated to have useful functional properties and a high non-extractable concentration of phenolic compounds. The stems have a high concentration of non-extractable polyphenols attached to polysaccharides, high antioxidant activity, and are a good substrate for bacterial growth. However, lees showed a high concentration of total neutral sugar and fibre with a good aptitude for the functional properties WRC and FAC. The skins gave high concentrations of galactose, arabinose and xylose. The results reveal that winemaking by-products can be considered sources of high-quality dietary fibre for food applications 
with good functional characteristics. However, further studies on the structures of the oligosaccharides involved would be necessary for a better understanding of grape stems as prebiotics.

Author Contributions: Conceptualization, R.C., A.M. and M.d.G.C.; methodology, R.C., S.R.-M. and M.J.B. formal analysis, M.Á.R.; investigation, M.Á.R.; resources, M.Á.R. and F.P.-N.; data management, R.C. and A.M.; writing—original draft preparation, M.Á.R. and R.C.; writing-review and editing, R.C. and F.P.-N.; visualization, A.M.; supervision, M.J.B. and M.d.G.C.; funding acquisition, M.d.G.C. All authors have read and agreed to the published version of the manuscript.

Funding: Junta de Extremadura with the projects IB16158, TA18007 and GR18165.

Institutional Review Board Statement: Not applicable.

Informed Consent Statement: Not applicable.

Data Availability Statement: Not applicable.

Acknowledgments: The authors are grateful to M. Cabrero and J. Hernández Barreto for technical assistance.

Conflicts of Interest: The authors declare no conflict of interest.

\section{References}

1. Food and Agriculture Organization Corporate Statistical Database (2017). FAO Database. Available online: http:/ / faostat.fao.org (accessed on 26 May 2021).

2. Bordiga, M.; Travaglia, F.; Locatelli, M.; Arlorio, M.; Coïsson, J.D. Spent grape pomace as a still potential by-product. Int. J. Food Sci. Technol. 2015, 50, 2022-2031. [CrossRef]

3. Fontana, A.R.; Antoniolli, A.; Bottini, R. Grape Pomace as a Sustainable Source of Bioactive Compounds: Extraction, Characterization, and Biotechnological Applications of Phenolics. J. Agric. Food Chem. 2013, 61, 8987-9003. [CrossRef]

4. González-Paramás, A.M.; Esteban-Ruano, S.; Santos-Buelga, C.; de Pascual-Teresa, S.; Rivas-Gonzalo, J.C. Flavanol Content and Antioxidant Activity in Winery Byproducts. J. Agric. Food Chem. 2004, 52, 234-238. [CrossRef]

5. Chowdhary, P.; Gupta, A.; Gnansounou, E.; Pandey, A.; Chaturvedi, P. Current trends and possibilities for exploitation of Grape pomace as a potential source for value addition. Environ. Pollut. 2021, 278, 116796. [CrossRef]

6. Lucarini, M.; Durazzo, A.; Kiefer, J.; Santini, A.; Lombardi-Boccia, G.; Souto, E.; Romani, A.; Lampe, A.; Nicoli, S.F.; Gabrielli, P.; et al. Grape Seeds: Chromatographic Profile of Fatty Acids and Phenolic Compounds and Qualitative Analysis by FTIR-ATR Spectroscopy. Foods 2019, 9, 10. [CrossRef]

7. González-Ballesteros, N.; Rodríguez-González, J.; Rodríguez-Argüelles, M. Harnessing the wine dregs: An approach towards a more sustainable synthesis of gold and silver nanoparticles. J. Photochem. Photobiol. B Biol. 2018, 178, 302-309. [CrossRef] [PubMed]

8. Basanta, R.; Delgado, M.A.G.; Martínez, J.E.C.; Vázquez, H.M.; Vázquez, G.B. Sustainability of waste recycling from the sugar agribusiness: A review. Cienc. Tecnol. Aliment. 2007, 5, 293-305. [CrossRef]

9. Bonamente, E.; Scrucca, F.; Asdrubali, F.; Cotana, F.; Presciutti, A. The Water Footprint of the Wine Industry: Implementation of an Assessment Methodology and Application to a Case Study. Sustainability 2015, 7, 12190-12208. [CrossRef]

10. De Iseppi, A.; Lomolino, G.; Marangon, M.; Curioni, A. Current and future strategies for wine yeast lees valorization. Food Res. Int. 2020, 137, 109352. [CrossRef]

11. Lavelli, V.; Torri, L.; Zeppa, G.; Fiori, L.; Spigno, G. Recovery of winemaking by-products for innovative food applications-A review. Ital. J. Food Sci. 2016, 28, 542-564.

12. Guadalupe, Z.; Ayestarán, B. Polysaccharide Profile and Content during the Vinification and Aging of Tempranillo Red Wines. J. Agric. Food Chem. 2007, 55, 10720-10728. [CrossRef] [PubMed]

13. Sánchez-Alonso, I.; Borderias, A.J. Technological effect of red grape antioxidant dietary fibre added to minced fish muscle. Int. J. Food Sci. Technol. 2008, 43, 1009-1018. [CrossRef]

14. Sáyago-Ayerdi, S.; Brenes, A.; Goñi, I. Effect of grape antioxidant dietary fiber on the lipid oxidation of raw and cooked chicken hamburgers. LWT 2009, 42, 971-976. [CrossRef]

15. Vidal, S.; Williams, P.; Doco, T.; Moutounet, M.; Pellerin, P. The polysaccharides of red wine: Total fractionation and characterization. Carbohydr. Polym. 2003, 54, 439-447. [CrossRef]

16. Corrales, M.; Toepfl, S.; Butz, P.; Knorr, D.; Tauscher, B. Extraction of anthocyanins from grape by-products assisted by ultrasonics, high hydrostatic pressure or pulsed electric fields: A comparison. Innov. Food Sci. Emerg. Technol. 2008, 9, 85-91. [CrossRef]

17. García-Gasca, T.; Castro, V.C.; García-Gasca, T.; Cruz, F.C.M.D.L. Nutraceutical Characterization and Sensory Analysis of Red Grape Bagasse Tea. 2008. Available online: www.uaq.mx/investigacion/difusion/veranos/memorias-2008/1 0VeranoRegionCentro/33UAZChavezCastroMunozdelaCruz.pdf (accessed on 23 January 2021). 
18. Pérez-Jiménez, J.; Sayago-Ayerdi, S.G. Grape antioxidant dietary fibre: A natural food additive and a dietary supplement. Agro-Food-Ind. Hi Tech 2009, 20, 17-19.

19. Rivas, M.Á.; Casquete, R.; Córdoba, M.D.G.; Benito, M.J.; Hernández, A.; Ruiz-Moyano, S.; Martín, A. Functional properties of extracts and residual dietary fibre from pomegranate (Punica granatum L.) peel obtained with different supercritical fluid conditions. LWT 2021, 145, 111305. [CrossRef]

20. Yu, J.; Ahmedna, M. Functional components of grape pomace: Their composition, biological properties and potential applications. Int. J. Food Sci. Technol. 2012, 48, 221-237. [CrossRef]

21. Mildner-Szkudlarz, S.; Bajerska, J.; Zawirska-Wojtasiak, R.; Górecka, D. White grape pomace as a source of dietary fibre and polyphenols and its effect on physical and nutraceutical characteristics of wheat biscuits. J. Sci. Food Agric. 2013, 93, 389-395. [CrossRef]

22. Sánchez-Alonso, I.; Borderías, J.; Larsson, K.; Undeland, I. Inhibition of Hemoglobin-Mediated Oxidation of Regular and Lipid-Fortified Washed Cod Mince by a White Grape Dietary Fiber. J. Agric. Food Chem. 2007, 55, 5299-5305. [CrossRef]

23. Özvural, E.B.; Vural, H. Grape seed flour is a viable ingredient to improve the nutritional profile and reduce lipid oxidation of frankfurters. Meat Sci. 2011, 88, 179-183. [CrossRef] [PubMed]

24. Guerrero, R.F.; Smith, P.; Bindon, K.A. Application of Insoluble Fibers in the Fining of Wine Phenolics. J. Agric. Food Chem. 2013, 61, 4424-4432. [CrossRef] [PubMed]

25. Álvarez, E.E.; Sánchez, P.G. La fibra dietética. Nutr. Hosp. 2006, 21, 61-72.

26. Grigelmo-Miguel, N.; Martín-Belloso, O. Characterization of dietary fiber from orange juice extraction. Food Res. Int. 1998, 31, 355-361. [CrossRef]

27. Mehta, N.; Ahlawat, S.S.; Sharma, D.P.; Dabur, R. Novel trends in development of dietary fiber rich meat products-A critical review. J. Food Sci. Technol. 2013, 52, 633-647. [CrossRef]

28. Baenas, N.; Nuñez-Gómez, V.; Navarro-González, I.; Sánchez-Martínez, L.; García-Alonso, J.; Periago, M.J.; González-Barrio, R. Raspberry dietary fibre: Chemical properties, functional evaluation and prebiotic in vitro effect. LWT 2020, 134, 110140. [CrossRef]

29. López-Oliva, M.E.; Torres, A.A.; Goñi, I.; Muñoz-Martínez, E. Grape antioxidant dietary fibre reduced apoptosis and induced a pro-reducing shift in the glutathione redox state of the rat proximal colonic mucosa. Br. J. Nutr. 2009, 103, 1110-1117. [CrossRef]

30. Pozuelo, M.J.; Torres, A.A.; Hervert-Hernández, D.; López-Oliva, M.E.; Muñoz-Martínez, E.; Rotger, R.; Goñi, I. Grape Antioxidant Dietary Fiber Stimulates Lactobacillus Growth in Rat Cecum. J. Food Sci. 2012, 77, H59-H62. [CrossRef]

31. Sun, H.-Y.; Ma, N.; Pan, T.; Du, C.-L.; Sun, J.-Y. Punicagranine, a new pyrrolizine alkaloid with anti-inflammatory activity from the peels of Punica granatum. Tetrahedron Lett. 2019, 60, 1231-1233. [CrossRef]

32. Sánchez-Tena, S.; Lizárraga, D.; Miranda, A.; Vinardell, M.P.; Garcia-Garcia, F.; Dopazo, J.; Torres, J.; Saura-Calixto, F.; Capella, G.; Cascante, M. Grape antioxidant dietary fiber inhibits intestinal polyposis in Apc Min/+ mice: Relation to cell cycle and immune response. Carcinogenesis 2013, 34, 1881-1888. [CrossRef]

33. Yusefi, M.; Shameli, K.; Ali, R.R.; Pang, S.-W.; Teow, S.-Y. Evaluating Anticancer Activity of Plant-Mediated Synthesized Iron Oxide Nanoparticles Using Punica granatum Fruit Peel Extract. J. Mol. Struct. 2020, 1204, 127539. [CrossRef]

34. AOAC International. Official Methods of Analysis 925.40, 19th ed.; AOAC International: Rockville, MD, USA, 2005.

35. AOAC International. Official Methods of Analysi 950.40s, 17th ed.; AOAC International: Rockville, MD, USA, 2000.

36. International Organization for Standardization. ISO 1444; International Organization for Standardization: Geneva, Switzerland, 1996.

37. Albalasmeh, A.; Berhe, A.A.; Ghezzehei, T. A new method for rapid determination of carbohydrate and total carbon concentrations using UV spectrophotometry. Carbohydr. Polym. 2013, 97, 253-261. [CrossRef]

38. Miller, G.L. Use of Dinitrosalicylic Acid Reagent for Determination of Reducing Sugar. Anal. Chem. 1959, 31, 426-428. [CrossRef]

39. Bastos, R.; Coelho, E.; Coimbra, M.A. Modifications of Saccharomyces pastorianus cell wall polysaccharides with brewing process. Carbohydr. Polym. 2015, 124, 322-330. [CrossRef] [PubMed]

40. AOAC International. Official Methods of Analysis 935.53, 17th ed.; AOAC International: Rockville, MD, USA, 2000.

41. Van Soest, P.J. Nutritional Ecology of the Ruminant, 2nd ed.; Cornell University Press: Ithaca, NY, USA, 1994.

42. Femenia, A.; García-Pascual, P.; Simal, S.; Rosselló, C. Effects of heat treatment and dehydration on bioactive polysaccharide acemannan and cell wall polymers from Aloe barbadensis Miller. Carbohydr. Polym. 2003, 51, 397-405. [CrossRef]

43. Van Handel, E. Direct microdetermination of sucrose. Anal. Biochem. 1968, 22, 280-283. [CrossRef]

44. Blumenkrantz, N.; Asboe-Hansen, G. New method for quantitative determination of uronic acids. Anal. Biochem. 1973, 54, 484-489. [CrossRef]

45. Garau, M.C.; Simal, S.; Rosselló, C.; Femenia, A. Effect of air-drying temperature on physico-chemical properties of dietary fibre and antioxidant capacity of orange (Citrus aurantium v. Canoneta) by-products. Food Chem. 2007, 104, 1014-1024. [CrossRef]

46. Arranz, S.; Saura-Calixto, F.; Shaha, S.; Kroon, P.A. High Contents of Nonextractable Polyphenols in Fruits Suggest That Polyphenol Contents of Plant Foods Have Been Underestimated. J. Agric. Food Chem. 2009, 57, 7298-7303. [CrossRef]

47. Wettasinghe, M.; Shahidi, F. Antioxidant and free radical-scavenging properties of ethanolic extracts of defatted borage (Borago officinalis L.) seeds. Food Chem. 1999, 67, 399-414. [CrossRef] 
48. Teixeira, D.M.; Canelas, V.C.; Canto, A.M.D.; Teixeira, J.M.G.; Dias, C.B. HPLC-DAD Quantification of Phenolic Compounds Contributing to the Antioxidant Activity of Maclura pomifera, Ficus carica and Ficus elastica Extracts. Anal. Lett. 2009, 42, $2986-3003$. [CrossRef]

49. Re, R.; Pellegrini, N.; Proteggente, A.; Pannala, A.; Yang, M.; Rice-Evans, C. Antioxidant activity applying an improved ABTS radical cation decolorization assay. Free Radic. Biol. Med. 1999, 26, 1231-1237. [CrossRef]

50. Ruiz-Moyano, S.; dos Santos, M.T.P.G.; Galván, A.I.; Merchán, A.V.; González, E.; Córdoba, M.D.G.; Benito, M.J. Screening of autochthonous lactic acid bacteria strains from artisanal soft cheese: Probiotic characteristics and prebiotic metabolism. LWT 2019, 114, 108388. [CrossRef]

51. Ruiz-Moyano, S.; Martín, A.; Benito, M.J.; Casquete, R.; Serradilla, M.J.; Córdoba, M.D.G. Safety and functional aspects of pre-selected lactobacilli for probiotic use in Iberian dry-fermented sausages. Meat Sci. 2009, 83, 460-467. [CrossRef]

52. Ruiz-Moyano, S.; Martín, A.; Benito, M.J.; Aranda, E.; Casquete, R.; Córdoba, M.D.G. Safety and Functional Aspects of Preselected Enterococci for Probiotic Use in Iberian Dry-Fermented Sausages. J. Food Sci. 2009, 74, M398-M404. [CrossRef]

53. Rubio, E.; Carmona, Y.; Igartuburu, J.M.; García, C.; Macías, D.F.A.; García, M.D.V. Study of the Composition of Winemaking Residues for Food Purposes. Available online: http:/ / hdl.handle.net/10498/16312 (accessed on 26 January 2021).

54. Deng, Q.; Penner, M.H.; Zhao, Y. Chemical composition of dietary fiber and polyphenols of five different varieties of wine grape pomace skins. Food Res. Int. 2011, 44, 2712-2720. [CrossRef]

55. González-Centeno, M.; Rosselló, C.; Simal, S.; Garau, M.; López, F.; Femenia, A. Physico-chemical properties of cell wall materials obtained from ten grape varieties and their byproducts: Grape pomaces and stems. LWT 2010, 43, 1580-1586. [CrossRef]

56. Bordiga, M. Valorization of Wine Making By-Products; CRC Press: Boca Raton, FL, USA, 2016.

57. Charpentier, C.; Feuillat, M. Élevage des vins rouges sur lies. Incidence de l'additiond'une $\beta$-glucanase sur la composition en polysaccharides et leurs interactions avec les polyphénols. Rev. Oenol. 2008, 35, 31-35.

58. Llobera, A.; Cañellas, J. Antioxidant activity and dietary fibre of Prensal Blanc white grape (Vitis vinifera) by-products. Int. J. Food Sci. Technol. 2008, 43, 1953-1959. [CrossRef]

59. Llobera, A.; Cañellas, J. Dietary fibre content and antioxidant activity of Manto Negro red grape (Vitis vinifera): Pomace and stem. Food Chem. 2007, 101, 659-666. [CrossRef]

60. Maurer, L.H.; Cazarin, C.B.B.; Quatrin, A.; Minuzzi, N.M.; Costa, E.L.; Morari, J.; Velloso, L.A.; Leal, R.; Rodrigues, E.; Bochi, V.C.; et al. Grape peel powder promotes intestinal barrier homeostasis in acute TNBS-colitis: A major role for dietary fiber and fiber-bound polyphenols. Food Res. Int. 2019, 123, 425-439. [CrossRef] [PubMed]

61. Pérez-Bibbins, B.; Torrado-Agrasar, A.; Salgado, J.; Oliveira, R.; Domínguez, J.M. Potential of lees from wine, beer and cider manufacturing as a source of economic nutrients: An overview. Waste Manag. 2015, 40, 72-81. [CrossRef] [PubMed]

62. Bender, A.B.B.; Speroni, C.S.; Moro, K.I.; Morisso, F.D.P.; dos Santos, D.R.; da Silva, L.P.; Penna, N.G. Effects of micronization on dietary fiber composition, physicochemical properties, phenolic compounds, and antioxidant capacity of grape pomace and its dietary fiber concentrate. LWT 2020, 117, 108652. [CrossRef]

63. Ping, L.; Pizzi, A.; Guo, Z.D.; Brosse, N. Condensed tannins extraction from grape pomace: Characterization and utilization as wood adhesives for wood particleboard. Ind. Crops Prod. 2011, 34, 907-914. [CrossRef]

64. Prozil, S.O.; Evtuguin, D.V.; Lopes, L.P.C. Chemical composition of grape stalks of Vitis vinifera L. from red grape pomaces. Ind. Crops Prod. 2012, 35, 178-184. [CrossRef]

65. Tseng, A.; Zhao, Y. Effect of Different Drying Methods and Storage Time on the Retention of Bioactive Compounds and Antibacterial Activity of Wine Grape Pomace (Pinot Noir and Merlot). J. Food Sci. 2012, 77, H192-H201. [CrossRef]

66. Apolinar-Valiente, R.; Romero-Cascales, I.; Gómez-Plaza, E.; López-Roca, J.M.; Ros-García, J.M. The composition of cell walls from grape marcs is affected by grape origin and enological technique. Food Chem. 2015, 167, 370-377. [CrossRef]

67. Arnous, A.; Meyer, A.S. Quantitative Prediction of Cell Wall Polysaccharide Composition in Grape (Vitis vinifera L.) and Apple (Malus domestica) Skins from Acid Hydrolysis Monosaccharide Profiles. J. Agric. Food Chem. 2009, 57, 3611-3619. [CrossRef]

68. Igartuburu, J.; Pando, E.; Luis, F.R.; Gil-Serrano, A. An acidic xyloglucan from grape skins. Phytochemistry 1997, 46, 1307-1312. [CrossRef]

69. Ortega-Regules, A.; Ros-García, J.M.; Bautista-Ortín, A.B.; López-Roca, J.M.; Gómez-Plaza, E. Changes in skin cell wall composition during the maturation of four premium wine grape varieties. J. Sci. Food Agric. 2008, 88, 420-428. [CrossRef]

70. Romero-Cascales, I.; Ros-García, J.; López-Roca, J.; Gómez-Plaza, E. The effect of a commercial pectolytic enzyme on grape skin cell wall degradation and colour evolution during the maceration process. Food Chem. 2012, 130, 626-631. [CrossRef]

71. Scheller, H.V.; Ulvskov, P. Hemicelluloses. Annu. Rev. Plant Biol. 2010, 61, 263-289. [CrossRef]

72. Ortega-Regules, A.; Ros-García, J.M.; Bautista-Ortín, A.B.; López-Roca, J.M.; Gómez-Plaza, E. Differences in morphology and composition of skin and pulp cell walls from grapes (Vitis vinifera L.): Technological implications. Eur. Food Res. Technol. 2007, 227, 223-231. [CrossRef]

73. Hernández-Hierro, J.M.; Quijada-Morín, N.; Martínez-Lapuente, L.; Guadalupe, Z.; Ayestarán, B.; Rivas-Gonzalo, J.-C.; EscribanoBailón, M.T. Relationship between skin cell wall composition and anthocyanin extractability of Vitis vinifera L. cv. Tempranillo at different grape ripeness degree. Food Chem. 2014, 146, 41-47. [CrossRef] [PubMed]

74. Ayestarán, B.; Guadalupe, Z.; León, D. Quantification of major grape polysaccharides (Tempranillo v.) released by maceration enzymes during the fermentation process. Anal. Chim. Acta 2004, 513, 29-39. [CrossRef] 
75. Fernández, O.; Martínez, O.; Hernández, Z.; Guadalupe, Z.; Ayestarán, B. Effect of the presence of lysated lees on polysaccharides, color and main phenolic compounds of red wine during barrel ageing. Food Res. Int. 2011, 44, 84-91. [CrossRef]

76. Elleuch, M.; Bedigian, D.; Roiseux, O.; Besbes, S.; Blecker, C.; Attia, H. Dietary fibre and fibre-rich by-products of food processing Characterisation, technological functionality and commercial applications: A review. Food Chem. 2011, 124, 411-421. [CrossRef]

77. Chau, C.-F.; Wang, Y.-T.; Wen, Y.-L. Different micronization methods significantly improve the functionality of carrot insoluble fibre. Food Chem. 2007, 100, 1402-1408. [CrossRef]

78. Lattimer, J.; Haub, M.D. Effects of Dietary Fiber and Its Components on Metabolic Health. Nutrient 2010, 2, 1266-1289. [CrossRef] [PubMed]

79. Navarro-González, I.; García-Valverde, V.; García-Alonso, J.; Periago, M.J. Chemical profile, functional and antioxidant properties of tomato peel fiber. Food Res. Int. 2011, 44, 1528-1535. [CrossRef]

80. Luo, X.; Wang, Q.; Fang, D.; Zhuang, W.; Chen, C.; Jiang, W.; Zheng, Y. Modification of insoluble dietary fibers from bamboo shoot shell: Structural characterization and functional properties. Int. J. Biol. Macromol. 2018, 120, 1461-1467. [CrossRef]

81. Putrino, F.M.; Tedesco, M.; Bodini, R.B.; de Oliveira, A.L. Study of supercritical carbon dioxide pretreatment processes on green coconut fiber to enhance enzymatic hydrolysis of cellulose. Bioresour. Technol. 2020, 309, 123387. [CrossRef] [PubMed]

82. Ferri, M.; Bin, S.; Vallini, V.; Fava, F.; Michelini, E.; Roda, A.; Minnucci, G.; Bucchi, G.; Tassoni, A. Recovery of polyphenols from red grape pomace and assessment of their antioxidant and anti-cholesterol activities. New Biotechnol. 2016, 33, 338-344. [CrossRef] [PubMed]

83. Hasnaoui, N.; Wathelet, B.; Jiménez-Araujo, A. Valorization of pomegranate peel from 12 cultivars: Dietary fibre composition, antioxidant capacity and functional properties. Food Chem. 2014, 160, 196-203. [CrossRef]

84. Peixoto, C.M.; Dias, M.I.; Alves, M.J.; Calhelha, R.C.; Barros, L.; Pinho, S.P.; Ferreira, I.C. Grape pomace as a source of phenolic compounds and diverse bioactive properties. Food Chem. 2018, 253, 132-138. [CrossRef] [PubMed]

85. Landete, J.M.; Rodríguez, H.; Rivas, B.D.L.; Muñoz, R. High-Added-Value Antioxidants Obtained from the Degradation of Wine Phenolics by Lactobacillus plantarum. J. Food Prot. 2007, 70, 2670-2675. [CrossRef] 